\title{
Genetic differentiation of the bullhead Cottus gobio L. across watersheds in Central Europe: evidence for two taxa
}

\author{
B. HÄNFLING*† \& R. BRANDL $\ddagger$ \\ †Lehrstuhl für Tierökologie I, Universität Bayreuth, Universitätsstr. 30, D-95440 Bayreuth, Germany and \\ ł.Umweltforschungszentrum Leipzig-Halle GmbH, Sektion Biozönoseforschung, Hallesche Str. 44, D-06246 Bad \\ Lauchstädt, Germany
}

\begin{abstract}
Starch gel electrophoresis and morphological characters were used to analyse the geographical variation of 16 populations of Cottus gobio, the bullhead, across three Central European drainage systems. Twenty out of 31 screened allozyme loci were polymorphic. Genetic variability differed considerably among populations $\left(H_{\mathrm{e}}\right.$ between 0.008 and 0.099$)$. Populations of the Danube and Elbe were significantly less variable than the Rhine populations. This is interpreted as a consequence of the smaller population sizes of the bullhead within the parts of the Danube and Elbe investigated. An $F_{\mathrm{ST}}$ value of 0.73 showed that the bullhead is one of the most highly structured freshwater fish species. High genetic distances and morphological differences indicated the existence of two well-defined taxa, one within the Rhine system and one within the Danube and Elbe systems. Genetic distance between these two taxa is about 0.24 (Nei's unbiased distance). Time estimates showed that the two taxa were probably originally separated by palaeogeographical events at the Pliocene/Pleistocene change.
\end{abstract}

Keywords: allozymes, biogeography, Cottus gobio, freshwater fish, morphometrics, population genetics.

\section{Introduction}

European fish populations have declined dramatically during the last few decades. For example, 72 per cent of German fish species are listed as endangered (Bless et al., 1994). Furthermore, because of the possible strong genetic differentiation of local fish populations (stocks), even the extinction of some local populations will reduce the genetic diversity of the fish fauna (articles in Ryman, 1981; Meffe, 1990; Ryman et al., 1995). Thus, fish ecologists have realized that efficient conservation strategies require knowledge of geographical population structure. Recent approaches to this problem in Europe have focused on economically important species, particularly salmonids (Riffel et al., 1995; Apostolidis et al., 1996; Koljonen \& McKinnell, 1996; Nielsen et al., 1996; Sanchez et al., 1996). These studies suggest a considerable subdivision of species into genetically differentiated stocks. However, salmonids are only a small part of the European fish fauna (17 per cent) and generalizations from these studies may be misleading. Furthermore most of the salmonid populations studied were anadromous. Only a few

*Correspondence: Umweltforschungszentrum Leipzig-Halle GmbH, Sektion Biozönoseforschung, Hallesche Str. 44, D-06246 Bad Lauchstädt, Germany. E-mail: hae@oesa.ufz.de taxa of primary freshwater fish (see Doadrio et al., 1996; Guinand et al., 1996) have been studied in Europe. The population history of primary freshwater fish differs from that of anadromous, as freshwater fish are even more restricted in their dispersal abilities. We expect that primary freshwater fish, especially small, sedentary species may show an even more pronounced genetic differentiation. In primary freshwater fish genetic differentiation within and across populations of different drainages should reflect historical and ecological influences on population structure.

The bullhead (Cottus gobio) appears to be an appropriate species in which to study geographical variation within and across drainages, for three reasons. (i) Despite its wide distributional range, the bullhead has a narrow ecological niche. The favoured habitats of this small, bottom-dwelling species are small brooks and the headwaters of rivers. (ii) No long-distance migrations have been recorded (Downhower et al., 1990; Waterstraat, 1992). Transport of spawn by waterfowl is also unlikely because of the low number of eggs laid on the undersides of stones (Lelek, 1987). (iii) Because C. gobio has no economical importance the original genetic population structure is not influenced by artificial stocking. 


\section{Materials and methods}

Populations of $C$. gobio were sampled in north-east Bavaria. This area is well suited for our study because it includes three important unconnected European drainage systems (Danube, Elbe and Rhine), and although the bullhead is endangered in Germany (Bless et al., 1994) it is common in the investigated area (Schadt, 1993). Thus, we were able to collect between 12 and 25 individuals (overall 296) at each of 16 sites across the three drainage systems (Fig. 1).

\section{Genetic differentiation}

Samples collected by electric fishing were stored in liquid nitrogen. We applied standard horizontal, starch gel electrophoresis using skeletal muscle and liver homogenates to characterize allozymes within and across sites. We scored four different buffer systems for each enzyme system to optimize conditions during electrophoreses. The screened enzyme systems and the selected buffer systems are listed in Table 1.

Analyses of genetic data were carried out with the programs BIOSYS-1 (Swofford \& Selander, 1989),

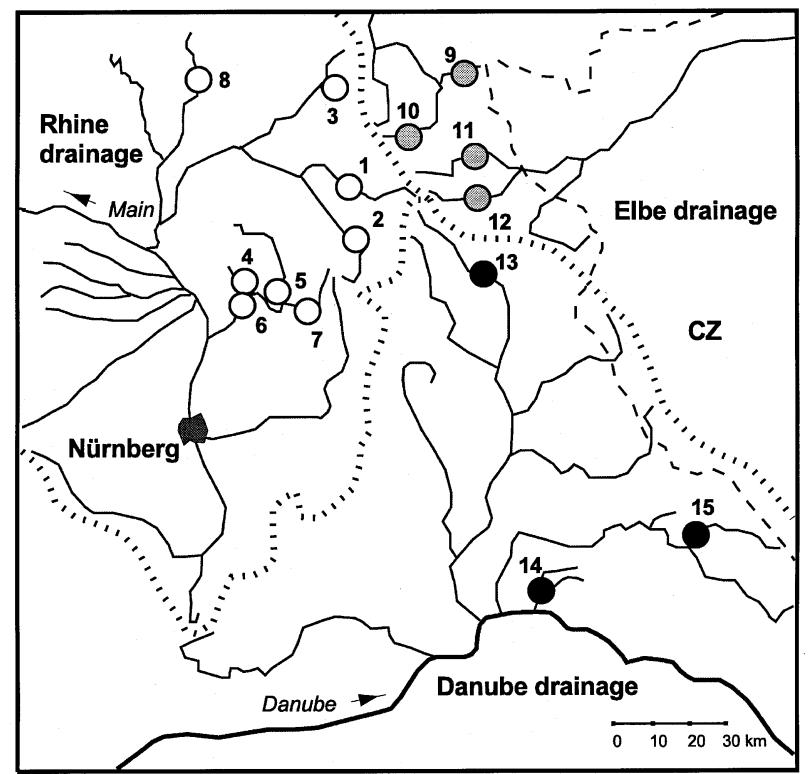

Fig. 1 Distribution of sampling localities for Cottus gobio in north-east Bavaria. Sampling sites are marked as white symbols (Rhine drainage), grey symbols (Elbe drainage) or black symbols (Danube drainage) The striped line represents the watershed between drainages, the broken line the border between Germany and the Czech Republic. Not shown is locality 16 (Loisach) from the southern part of the Danube drainage.
GENEPOP (Raymond \& Rousset, 1995), PHYLIP (Felsenstein, 1993) and NTSYs-pc (Rohlf, 1992) as follows. (i) The option 'Probability-test' of GENEPOP was used to test deviation of genotype frequencies of loci from Hardy-Weinberg equilibrium. Tests were combined across loci and across sites using Fisher's method. As a measure of genetic variability within samples we calculated the percentage of polymorphic loci $(P)$ and the mean expected heterozygosity across all loci $\left(H_{\mathrm{e}}\right)$ using BIOsYs-1. (ii) Differentiation among sites was evaluated by using the test of Raymond \& Rousset (1995), Wright's (1978) hierarchical $F$-statistics and Nei's (1978) unbiased genetic distance, using the option 'Genic differentiation for all populations' of GENEPOP and the appropriate steps of BIOSYs-1. $F$-statistics were used to partition genetic variation into three hierarchical components: sites, rivers and drainage system. For simplicity the names Rhine, Danube and Elbe were used to characterize the drainage systems, but it should be emphasized that the sample area includes only the north-east Bavarian parts of the three drainages. (iii) To summarize the distance matrix we performed a cluster analysis using the UPGMAmethod. Bootstrapping of the UPGMA-tree was performed with the appropriate programs within the PHYLIP package (Felsenstein, 1993).

\section{Morphological differentiation}

In addition to genetic data we scored some morphometric and meristic characters for each individual: body length, head length, distance between eyes, fin ray counts of the first and second dorsal fins, the anal fin, the pectoral fin (left and right) and the ventral fin (left and right). Fin ray counts were summed for paired fins. Morphometric characters were log-transformed. We performed univariate and multivariate analyses of morphological data as follows, using the appropriate procedures of GLIM4 or spss-pc. (i) Differences between drainages in distribution patterns of fin ray counts were tested by $\chi^{2}$-tests. (ii) Differences between drainages in the regressions of head length and distance between eyes vs. body length were tested by covariance analyses. (iii) Morphometric characters depend on age and size. Thus, for multivariate analysis, we calculated the residuals from a regression between head length and distance between eyes vs. body length to standardize for size. As a slope we used the pooled within-site slope (Thorpe, 1976). Residuals and raw meristic characters were than subjected to a discriminant analysis using sites as groups. (iv) Correlations between genetic and morphological 
data were tested by plotting Nei's unbiased distance (Nei, 1978) against the Mahalanobis distance between sites with NTSYs-pc using the Mantel test (see Rohlf, 1992).

\section{Results}

\section{Genetic differentiation}

We were able to score 19 enzyme systems consistently coding for 31 presumptive loci, of which 20 showed some allozymic variation (allele frequencies are available from authors by request). Distribution and frequencies of alleles across sites allowed for 59 tests for deviation from the Hardy-Weinberg equilibrium. Only one proved to be significant, which is not more than expected by chance. None of the combined tests (either combining across loci or across sites) was significant.

Heterozygosity was significantly correlated with the number of polymorphic loci $(r=0.94$; d.f. $=14$; $P<0.001)$ and we therefore concentrated on the expected heterozygosity. $H_{\mathrm{e}}$ of sites averaged over all loci ranged from 0.008 to 0.099 (mean $0.043 ; N=16$; Fig. 2). Averaging $H_{\mathrm{e}}$ over sites within a drainage showed significant differences among drainages (Rhine: $N=8$, mean $H_{\mathrm{e}} \pm \mathrm{SD}$ is $0.07 \pm 0.02$; Elbe: $N=4, H_{\mathrm{e}}=0.02 \pm 0.01$; Danube: $N=4, H_{\mathrm{e}}=0.03 \pm$ 0.02; Kruskal-Wallis ANOvA: $\chi_{2}^{2}=10.2 ; P=0.006$ ).

Only one of the 20 polymorphic loci showed no significant difference in its allelic composition across

Table 1 Enzyme systems, EC numbers, locus designations, tissue sources (M, muscle; L, liver) and buffer systems used. The last column gives the number of alleles detected for each locus. Enzyme nomenclature and locus designation follow Shaklee et al. (1990)

\begin{tabular}{|c|c|c|c|c|c|}
\hline Enzyme system & EC No. & Locus & Tissue & Buffer system $^{1}$ & No. of alleles \\
\hline \multirow[t]{2}{*}{ Aconitate hydratase } & \multirow[t]{2}{*}{ 4.2.1.3 } & $A C O H-1 *$ & $\mathrm{~L}$ & $\mathrm{~S} 4$ & 3 \\
\hline & & $\mathrm{ACOH}-2 *$ & $\mathrm{~L} / \mathrm{M}$ & $\mathrm{S} 4$ & 1 \\
\hline Acid phosphatase & 3.1.3.2 & $A C P^{*}$ & $\mathrm{~L}$ & S4 & 2 \\
\hline \multirow[t]{2}{*}{ Alcohol dehydrogenase } & \multirow[t]{2}{*}{ 1.1.1.1 } & $A D H-1^{*}$ & $\mathrm{~L}$ & EBT & 3 \\
\hline & & $A D H-2 *$ & $\mathrm{~L}$ & EBT & 3 \\
\hline \multirow[t]{3}{*}{ Aspartate aminotransferase } & \multirow[t]{3}{*}{ 2.6.1.1 } & $A A T-1 *$ & $\mathrm{~L}$ & S4 & 4 \\
\hline & & $A A T-2 *$ & $\mathrm{M} / \mathrm{L}$ & $\mathrm{S} 4$ & 2 \\
\hline & & $A A T-3 *$ & $\mathrm{M} / \mathrm{L}$ & $\mathrm{S} 4$ & 2 \\
\hline \multirow[t]{4}{*}{ Esterase } & \multirow[t]{4}{*}{ 3.1.1.x } & EST-1* & $\mathrm{L} / \mathrm{M}$ & S1 & 4 \\
\hline & & EST-2* & $\mathrm{L}$ & TCE & 4 \\
\hline & & EST-3* & $\mathrm{M} / \mathrm{L}$ & EBT & 4 \\
\hline & & EST-4* & $\mathrm{L}$ & S1 & 2 \\
\hline Fructose-bisphosphatase & 3.1.3.1 & $F B P^{*}$ & $\mathrm{~L}$ & TCE & 1 \\
\hline Glucose dehydrogenase & 1.1.1.118 & $G D H^{*}$ & $\mathrm{~L}$ & EBT & 1 \\
\hline \multirow[t]{3}{*}{ Glycerol-3-phosphate dehydrogenase } & \multirow[t]{3}{*}{ 1.1.1.8 } & $G 3 P D H-1 *$ & $\mathrm{~L}$ & TCE & 2 \\
\hline & & $G 3 D P H-2 *$ & $\mathrm{~L}$ & TCE & 1 \\
\hline & & $G 3 P D H-3 *$ & $\mathrm{M}$ & S4 & 2 \\
\hline \multirow[t]{2}{*}{ Glucose-6-phosphate isomerase } & \multirow[t]{2}{*}{ 5.3.1.9 } & $G P I-1^{*}$ & $\mathrm{M} / \mathrm{L}$ & $\mathrm{S} 4$ & 3 \\
\hline & & $G P I-2 *$ & $\mathrm{M} / \mathrm{L}$ & $\mathrm{S} 4$ & 2 \\
\hline \multirow[t]{2}{*}{ Isocitrate dehydrogenase } & \multirow[t]{2}{*}{ 1.1.1.42 } & $I D H P-1 *$ & $\mathrm{~L}$ & S4 & 1 \\
\hline & & $I D H P-2 *$ & M & EBT & 1 \\
\hline L-Iditol dehydrogenase & 1.1.1.14 & $I D D H^{*}$ & $\mathrm{~L}$ & S1 & 3 \\
\hline Lactate dehydrogenase & 1.1.1.27 & $L D H^{*}$ & M & EBT & 2 \\
\hline \multirow[t]{2}{*}{ Malate dehydrogenase } & \multirow[t]{2}{*}{ 1.1.1.37 } & $M D H-1 *$ & M & TCE & 2 \\
\hline & & $M D H-2 *$ & $\mathrm{~L}$ & TCE & 1 \\
\hline Malate dehydrogenase $\left(\mathrm{NADP}^{+}\right)$ & 1.1.1.40 & $M E P^{*}$ & M & EBT & 1 \\
\hline Mannose-6-phosphate isomerase & 5.3.1.8 & $M P I^{*}$ & $\mathrm{~L}$ & EBT & 1 \\
\hline Phosphoglucomutase & 5.4 .2 .2 & $P G M^{*}$ & $\mathrm{M} / \mathrm{L}$ & TCE & 2 \\
\hline Phosphogluconate dehydrogenase & 1.1.1.44 & $P G D H^{*}$ & $\mathrm{M} / \mathrm{L}$ & TCE & 2 \\
\hline \multirow[t]{2}{*}{ Superoxide dismutase } & \multirow[t]{2}{*}{1.15 .1 .1} & $S O D-1^{*}$ & $\mathrm{~L}$ & EBT & 1 \\
\hline & & $S O D-2 *$ & $\mathrm{~L} / \mathrm{M}$ & EBT & 1 \\
\hline
\end{tabular}

${ }^{1}$ S1: Tris-hydrochloric acid. Electrode $\mathrm{pH}$ 8.2/gel 8.5. S4: Tris-citrate. Electrode pH 6.0/gel pH 6.3. EBT: Tris-borateEDTA. Electrode/gel pH 8.6. TCE: Tris-citrate-EDTA. Electrode/gel pH 7.0. Buffer recipes were modified from Selander et al. (1971; S1 and S4) or from Hillis \& Moritz (1990; EBT and TCE). All staining procedures were performed according to Hillis \& Moritz (1990). 


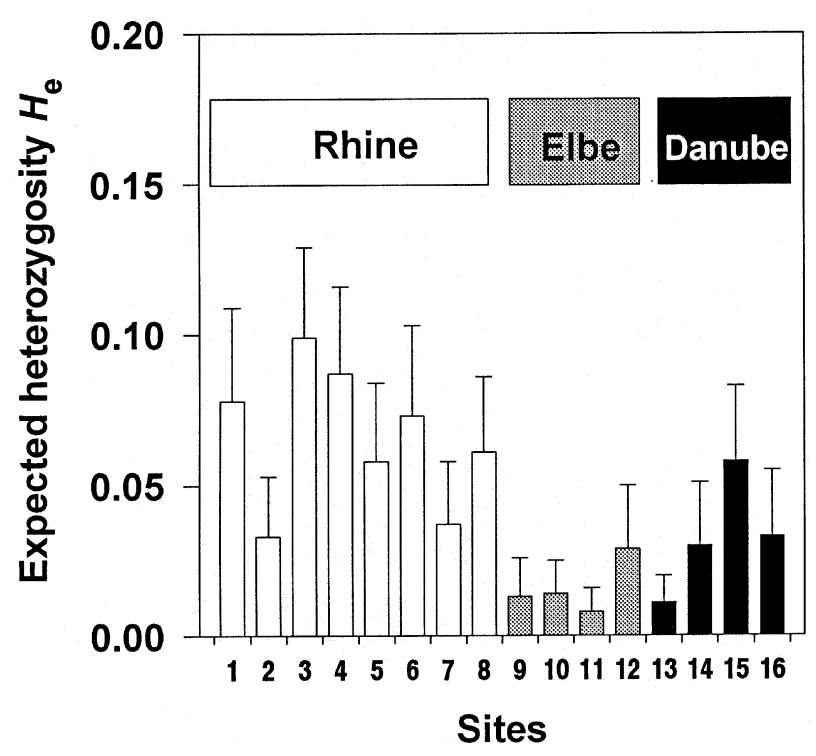

Fig. 2 Mean expected heterozygosity in 16 subpopulations of Cottus gobio with the associated standard errors.

sites $\left(L D H^{*} ; P=0.106\right)$. For all other loci genic differentiation across sites is highly significant $(P<0.0001)$. A partitioning of genetic variability indicated that 73 per cent of the genetic variability is attributable to differences among sites $\left(F_{\text {site/total }}=\right.$ $0.73)$ and 58 per cent is based on the differentiation among drainages $\left(F_{\text {drainage/total }}=0.58\right)$. There is no differentiation among rivers within a drainage $\left(F_{\text {river/drainage }}=-0.03\right)$. However, there is still a considerable variability between sites within a drainage $\left(F_{\text {site/drainage }}=0.35\right)$. The unbiased distances according to Nei (1978) between sites range from 0.006-0.358. Distances within one drainage were consistently lower than those between sites of different drainages (Fig. 3). The UPGMA-cluster analysis of the matrix of Nei distances (Fig. 3) emphasizes this strong geographical pattern. Bootstrapping provides significant support for the branches of the UPGMA-tree, which separates the Rhine drainage (97 per cent) as well as the Elbe (72 per cent) and Danube (78 per cent).

Five loci were fixed for different alleles between Rhine and Danube $\left(A D H-1^{*}, A A T-1^{*}, A A T-3^{*}\right.$, $\left.P G M^{*}, P G D H^{*}\right)$, three between Rhine and Elbe $\left(A A T-3^{*}, P G M^{*}, P G D H^{*}\right)$ and one between Elbe and Danube $(A D H-1 *)$.

\section{Morphometric differentiation}

All meristic and morphometric characters showed significant differences among drainages (Table 2,

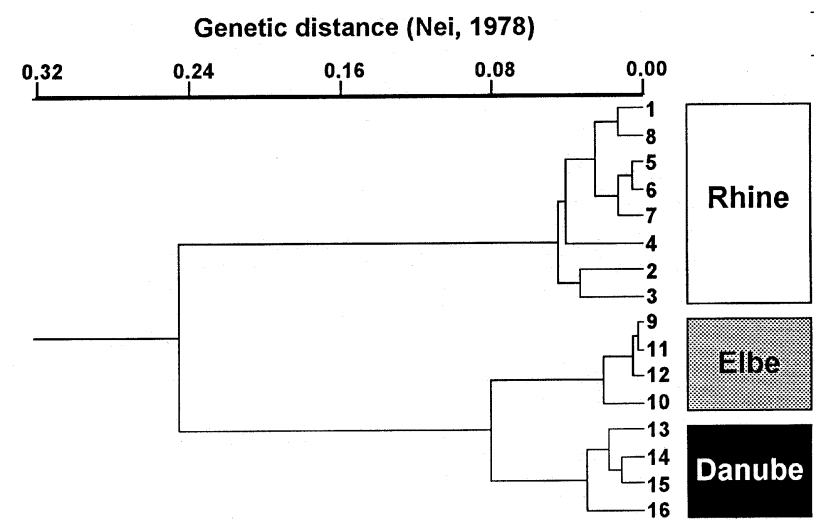

Fig. 3 UGPMA-cluster analysis of Nei distances calculated from 31 examined allozyme loci in 16 subpopulations of Cottus gobio from three Central European drainages.

Figs 4 and 5). The first and second functions of the discriminant analysis include nearly 77 per cent of the variance. A plot of the discriminant scores of individuals shows a separation of the individuals according to drainages (Fig. 6). Note that we used sites to group individuals for the discriminant analysis, thus the clustering of sites from one drainage in Fig. 6 is not an artefact of our analysis. The mean probability of correctly placing individuals into the predicted groups (sites) was 0.61 . However, 85 per cent were correctly classified among drainages. A comparison between Mahalanobis distances and Nei distances showed a weak correlation $(r=0.53$; $P=0.01 ; 100$ permutations, one-tailed test).

\section{Discussion}

Variability within sites

The average heterozygosity within all sites of C. gobio (0.042) corresponds very well with the average value for freshwater fish $(0.046)$ reported by Ward et al. (1994). However, in the present study heterozygosity differed significantly among drainages

Table 2 Comparison of fin ray counts in Cottus gobio across drainages by $\chi^{2}$-test. For analysis we grouped cells to achieve an expected frequency greater than 3

\begin{tabular}{lccc}
\hline $\begin{array}{l}\text { Meristic } \\
\text { character }\end{array}$ & $\begin{array}{c}\text { Range of } \\
\text { counts }\end{array}$ & $\begin{array}{c}\text { Grouped } \\
\text { cells }\end{array}$ & $\chi^{2}$ (d.f.) \\
\hline First dorsal fin & $5-9$ & $5-6,8-9$ & $95.0(4)^{* * *}$ \\
Second dorsal fin & $15-19$ & $15-16$ & $52.2(6)^{* * *}$ \\
Anal fin & $12-16$ & $15-16$ & $40.7(6)^{* * *}$ \\
Pectoral fin (sum) & $26-30$ & $26-27,29-30$ & $13.7(4)^{* * *}$ \\
Ventral fin (sum) & $6-10$ & $6-7,8-10$ & $26.8(2)^{* * *}$ \\
\hline
\end{tabular}

${ }^{* *} P<0.01,{ }^{* * *} P<0.001$. 
(Fig. 2). The sites investigated in the Rhine drainage show a high genetic variation (well above the average value of Ward et al., 1994), whereas Danube and Elbe sites show a low level of heterozygosity (well below the value of Ward et al., 1994). In northeast Bavaria the bullhead is widely distributed with large population sizes within the Rhine drainage. The populations in the Danube and Elbe, however, are quite isolated and small (Schadt, 1993). Southwest German populations of the bullhead investigated by Riffel \& Schreiber (1995) showed a mean heterozygosity similar to our estimates from the Danube and Elbe drainages (mean $H_{\mathrm{e}}=0.017$ ). According to Riffel (personal communication) these populations are also all quite small. We conclude (a)

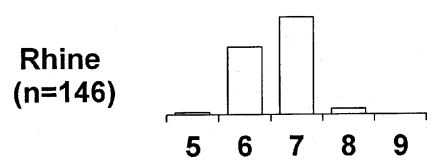

Elbe

$(n=78)$
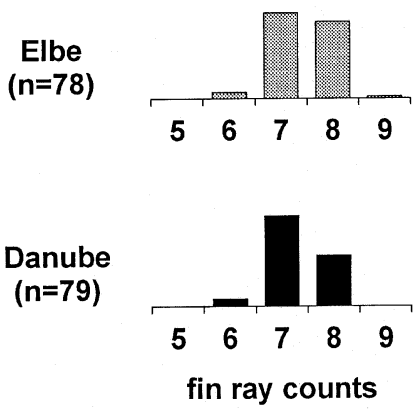

(b)
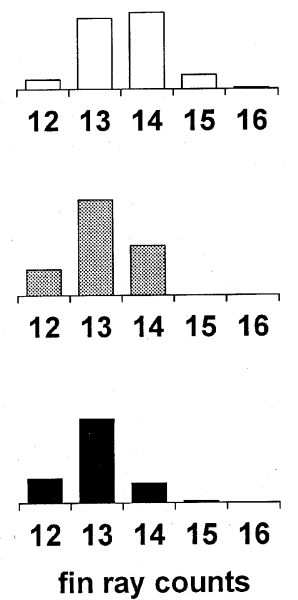

Fig. 4 Distribution of fin ray counts of (a) the first dorsal fin and (b) the anal fin of Cottus gobio in the three investigated drainages. that the genetic diversity within sites is predominantly influenced by the size and isolation of the population under consideration. Thus the level of heterozygosity within sites indicates the status and isolation of local populations (Frankham, 1996; Young et al., 1996).

\section{Differentiation between sites}

Compared to the surveys of Ward et al. (1994) and Gyllensten (1985), the degree of intrapopulational differentiation is one of the highest found within a fish species. Cluster analysis of genetic distances showed a clear geographical pattern. Two major stocks can be identified which are separated by a Nei distance of 0.24 . A recent study by Riffel \& Schreiber (1995) also found genetically differentiated stocks of the bullhead in the south-west German part of the Danube and Rhine drainages. However, these stocks show no clear separation according to the two drainages: one is formed by most of the samples of the Neckar (Rhine drainage), the other stock is formed by samples from the Danube and Upper Rhine. These two stocks have a genetic distance of 0.21 , a value similar to the distance between the major stocks identified in our study. Riffel \& Schreiber (1995) used agarose gels to characterize their alleles. Thus a direct comparison to our study (we used starch gels) is not possible. However, we were able to use some individuals from the samples of Riffel \& Schreiber (1995) during our experiments and we found identical alleles for the loci $P G M^{*}$ and $P G D H^{*}$, which allowed us to compare the findings of the two studies. In both studies these two loci showed fixed differences between stocks. Based on the fixed differences of $P G M^{*}$ and $P G D H^{*}$ one may characterize two bullhead stocks in southern Germany: the 'Northern (a)

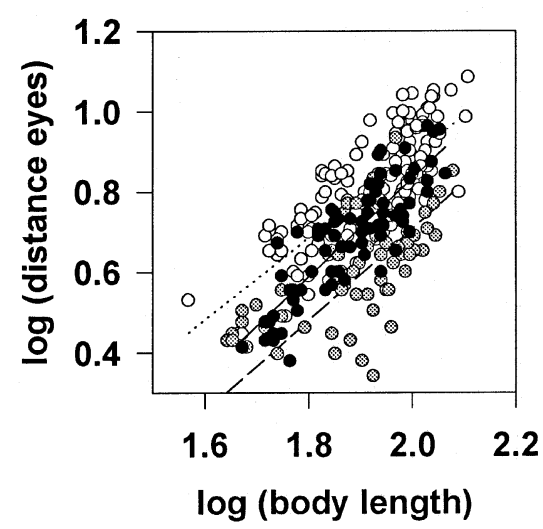

(b)

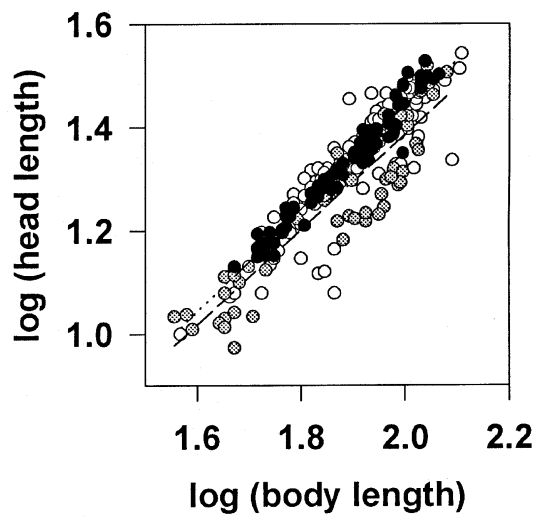

Fig. 5 Relationship of (a) distance between eyes and (b) head length to body length in Cottus gobio. Linear regressions are shown for each drainage as a dotted line (Rhine drainage), broken line (Elbe drainage) and full line (Danube drainage). For both variables there is no significant difference in slope (a: $F_{1,284}=1.4, P>0.05$; b: $\left.F_{1,284}=1.0, P>0.05\right)$ but there is between intercepts (a: $F_{1,286}=99.0, P<0.01 ;$ b: $\left.F_{1,286}=22.1, P<0.01\right)$. 
Group' combining populations from the Neckar and Main and the 'Southern Group' combining populations from the Danube, Elbe (at least the Bavarian part) and the Upper and Higher Rhine.

The results of the allozyme analysis are confirmed by univariate and multivariate analyses of morphological data. Morphological differences among drainages, however, are not as clear as the genetic data. Andoh \& Goto (1988) describe sympatric sibling species in the genus Cottus with only minor morphological differences. Thus, the degree of genetic and morphological differentiation is not well correlated within the genus Cottus. Morphological adaptations to environmental conditions (hydrodynamic conditions) may mask morphological differences with a genetic background.

\section{Systematic and evolutionary implications}

Thorpe (1982) suggested that when the species status of a population is unresolvable by other criteria information on genetic distance can be used. $\mathrm{He}$ suggested that allopatric populations with a

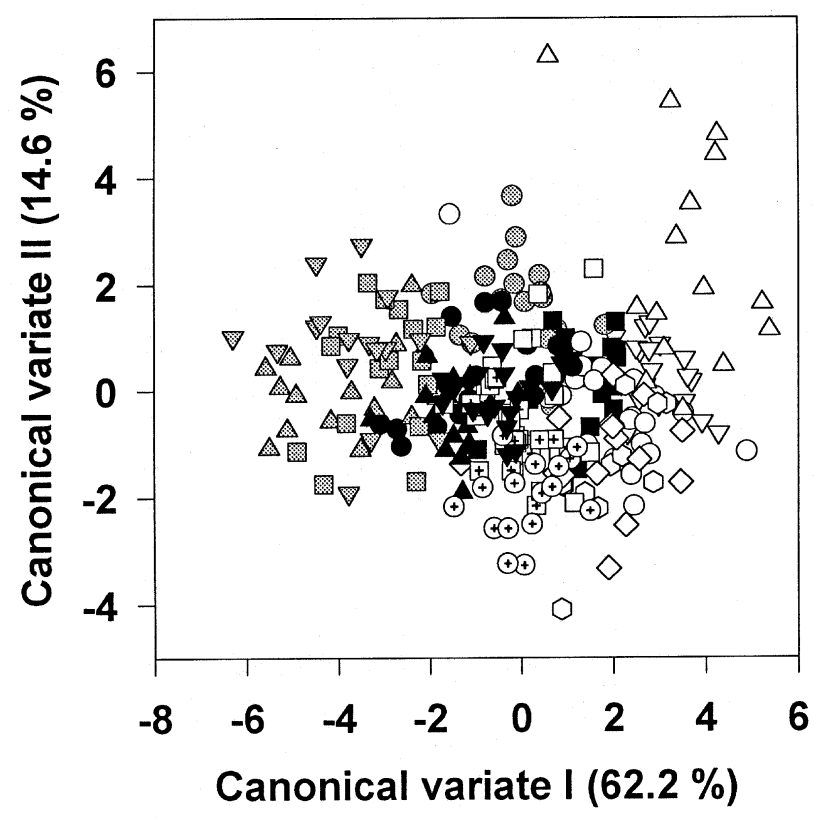

Fig. 6 Ordination of canonical variates of discriminant analysis of seven morphological characters in Cottus gobio (head length, distance between eyes, fin ray counts of the first and second dorsal fins, the anal fin, the pectoral fins and the ventral fins). Individuals are marked as white symbols (Rhine drainage), grey symbols (Elbe drainage) or black symbols (Danube drainage). Within each drainage individuals are marked with different symbols for each site.

(c) The Genetical Society of Great Britain, Heredity, 80, 110-117. distance above 0.16 may belong to different species. This criterion would classify the two stocks of $C$. gobius as two different species. Avise \& Aquadro (1982) calculated the mean Nei distance between freshwater species of one genus. They reported a value of about 0.36. Again this comparison shows that the mean distances between the two stocks of C. gobio is in the order of magnitude of interspecific difference and exceeds the value of intraspecific differentiation as reported in Ward et al. (1994). Two published studies on sympatric species of the genus Cottus confirm this conclusion. Zimmerman \& Wooten (1981) found a mean genetic distance of 0.20 between populations of Cottus confusus and $C$. cognatus. Andoh \& Goto (1988) calculated a mean distance of 0.22 between Cottus amblystomopsis and C. nozawae. The occurrence of fixed loci can also be used as a hint for different taxa. Avise (1994) compared taxa of the sunfish (Lepomis) in different stages of evolutionary divergence. In this study geographical populations showed no fixed differences, whereas about 15 per cent of loci have been fixed between subspecies and 50 per cent between species. Because in our study 10 per cent of the loci showed fixed differences between stocks they could be classified as two subspecies. As a conclusion we suggest that there are at least two different taxa of the bullhead in southern Germany. Whether these taxa are classified as subspecies or as sibling species is a matter of opinion.

Several authors have used allozyme data to obtain rough ideas about the time scale of evolutionary events (see Avise, 1994). However, there is no general calibration of the molecular clock. Even within fishes, authors suggested that depending on the taxon analysed, a Nei distance of one may correspond to a time estimate of between one (Avise et al., 1975) and 25 million years (Myr) (Doadrio et al., 1996). According to these calibrations the predicted divergence time of the two Cottus gobio stocks $(D=0.24)$ is at least 0.24 and at most 6 Myr. The study of Riffel \& Schreiber (1995) allows a more direct calibration of the molecular clock for Cottus populations. These authors analysed populations from the river Wutach, a small river draining to the Rhine valley. Palaeogeographical evidence, however, shows that during the Pleistocene the Wutach was part of the Danube drainage. The river capture of the Wutach happened during the Würm-glacial, 0.05-0.1 Myr ago (Hantke, 1993). The invasion of Cottus gobio from the Danube into the Rhine drainage was obviously not accompanied by introgression with the Rhine populations of the 'Northern stock', because the Wutach populations show the same 
fixed differences from the 'Northern stock' as do the Danube populations (Riffel \& Schreiber, 1995) and we thus suggest an effective isolation. Nei's genetic distance between the bullhead population of the Wutach (and two populations located nearby) and populations from the Danube is 0.04. Using the Wutach capture as a calibration of the molecular clock the divergence time of the stocks of the bullhead was somewhere between 0.3 and $0.6 \mathrm{Myr}$ ago and the divergence between populations within the Danube and Elbe would be between 0.1 and $0.2 \mathrm{Myr}$ ago.

\section{Biogeographical history}

The Rhine and the Danube drainages evolved at the end of the Tertiary. During the evolution of the river systems, the Danube permanently lost terrain to other drainages. At the Pliocene/Pleistocene boundary most parts of the Neckar, the Upper Rhine and the Upper Main/Regnitz changed their direction from the Danube to the Rhine system. Several smaller river captures from the Danube to the Rhine occurred during the Pleistocene. The most recent one was the capture of the Wutach mentioned earlier (Hantke, 1993). The Danube also lost some terrain to the Elbe drainage. The Upper Moldau is thought to have drained to the ancient Danube at least up to the end of the Miocene. Since the end of the Pleistocene the river systems have been more or less stable (Hantke, 1993).

Bănărescu (1991) suggested that many Central European fish species were displaced from the Atlantic-Baltic drainages during the Pleistocene and recolonized this area after the main glaciations. This refugium-recolonization hypothesis implies that the major events structuring the European fish fauna should date back to the Pleistocene. However, the calculated divergence time of the two major bullhead stocks suggests an older origin. Only the divergence time between the populations in the Danube and Elbe drainages supports this hypothesis.

A possible explanation for the divergence time of the 'Northern stock' and the 'Southern stock' of the bullhead starts with the assumption that the bullhead invaded Europe via the Danube drainage. Bănărescu $(1990,1991)$ suggests that most of the primary freshwater species with an eastern radiation centre used this biogeographical pathway. When the ancient Main/Regnitz system changed its direction from the Danube to the Rhine drainage, bullheads were able to invade the Rhine drainage. This would agree with the calculated divergence time. In conclusion we suggest that, although Pleistocene events may have influenced the genetic structure of the bullhead populations, the major events are much older and connected to palaeogeographical events influencing the catchment areas of the drainages.

\section{Acknow ledgements}

We thank the regional fishery authorities in northeast Bavaria (Dr R. Klupp, Bayreuth and Dr H. Schmeller, Regensburg) who organized the sampling of bullheads. Prof. Dr H. Stein provided bullheads from Loisach. The study was funded by the 'Landesfischereiverband Bayern'. Prof. Dr G. Bauer (Freiburg) helped during our first steps in fish genetics. F. Gebert, K. Kuhlen, L. Mayer, M. Popp and many other people helped in the field. Dr H. Auge worked through several drafts of the manuscript. K. Hempel designed the map.

\section{References}

ANDOH, T. AND GOTO, A. 1988. Biochemical evidence for reproductive isolation between sympatric populations of Cottus amblystomopsis and C. nozawae. Jap. J. Ichthyol., 35, 176-183.

APOSTOLIDIS, A. P., KARAKOUSIS, Y. AND TRIANTAPHYLLIDIS, C. 1996. Genetic differentiation and phylogenetic relationships among Greek Salmo trutta L. (brown trout) populations as revealed by RFLP analysis of PCR amplified mitochondrial DNA segments. Heredity, 77, 608-618.

AVISE, J. C. 1994. Molecular Markers, Natural History and Evolution. Chapman and Hall, New York.

AVISE, J. C. AND AQUADRO, C. F. 1982. A comparative study of genetic distances in vertebrates. Evol. Biol., 15, $158-185$.

AVISE, J. C., SMith, J. J. AND AyAla, F. J. 1975. Adaptive differentiation with little genic change between two native Californian minnows. Evolution, 29, 411-426.

BǍNǍreSCU, P. 1990. Zoogeography of Freshwaters, vol. 1. General Distribution and Dispersal of Freshwater Animals. Aula Verlag, Wiesbaden.

BǍNǍRESCU, P. 1991. Zoogeography of Freshwaters, vol. 2. Distribution and Dispersal of Freshwater Animals in North America and Eurasia. Aula Verlag, Wiesbaden.

Bless, R., LELEK, A. AND WATERstraAt, A. 1994. Rote Liste und Artenverzeichnis der in Deutschland in Binnengewässern vorkommenden Rundmäuler und Fische (Cyclostomata und Pisces). In: Nowak, E., Blab, J. and Bless, R. (eds) Rote Liste der Gefährdeten Wirbeltiere Deutschlands, pp. 137-154. Kilda-Verlag, Greven.

DOADRIO, I., PERDICES, A. AND MACHORDOM, A. 1996. Allozymic variation of the endangered killifish Aphanius iberius and its application to conservation. Envir. Biol. Fish., 45, 259-271.

DOWNHOWER, J. F., LEJEUNE, P., GAUDIN, P. AND BROWN, L. 1990. Movements of the chabot (Cottus gobio) in a small stream. Pol. Arch. Hydrobiol., 37, 119-126.

(C) The Genetical Society of Great Britain, Heredity, 80, 110-117. 
FELSENSTEIN, J. 1993. PHYLIP (Phylogeny inference package) version 3.5c. Department of Genetics, University of Washington, Seattle.

FRANKHAM, R. 1996. Relationship of genetic variation to population size in wildlife. Conserv. Biol., 10, 1500-1508.

GUINAND, B., BOUVET, Y. AND BROHON, B. 1996. Spatial aspects of genetic differentiation of the European chub in the Rhone River basin. J. Fish Biol., 49, 714-726.

GYLLENSTEN, U. 1985. The genetic structure of fish, differences in the intraspecific distribution of biochemical genetic variation between marine, anadromous and freshwater species. J. Fish Biol., 26, 691-699.

HANTKE, R. 1993. Flußgeschichte Mitteleuropas. Ferdinand Enke Verlag, Stuttgart.

HILlis, D. M. AND MORITZ, C. 1990. Molecular Systematics. Sinauer, Sunderland, MA.

KOLJONEN, M. L. AND McKINNELl, s. 1996. Assessing seasonal changes in stock composition of Atlantic salmon catches in the Baltic Sea with genetic stock identification. J. Fish Biol., 49, 998-1018.

LELEK, A. 1987. The Freshwater Fishes of Europe, vol. 9. Threatened Fishes of Europe. Aula-Verlag, Wiesbaden.

MEFFE, G. K. 1990. Genetic approaches to conservation of rare fishes: examples from North American desert species. J. Fish Biol., 37, 105-112.

NEI, M. 1978. Estimation of average heterozygosity and genetic distance from a small number of individuals. Genetics, 89, 583-590.

NIELSEN, E. E., HANSEN, M. M. AND LOESCHCKE, V. 1996. Genetic structure of European populations of Salmo salar L. (Atlantic salmon) inferred from mitochondrial DNA. Heredity, 77, 351-358.

RAYMOND, M. AND ROUSSET, F. 1995. GENEPOP (version 1.2): a population genetic software for exact tests and ecumenicism J. Hered., 86, 248-249.

RIFFEL, M. AND SCHREIBER, A. 1995. Coarse-grained population structure in Central European sculpin (Cottus gobio L.): secondary contact or ongoing genetic drift? J. Zool. Syst. Evol. Res., 33, 173-184.

RIFFEL, M., STORCH, v. AND SCHREIBER, A. 1995. Allozyme variability of brown trout (Salmo trutta L.) populations across the Rhenanian-Danubian watershed in southwest Germany. Heredity, 74, 241-249.

ROHLF, F. J. 1992. NTSYS-pc, Numerical taxonomy and multivariate analysis system, version 1.80. Applied Biostatistics, Setauket, NY.
Ryman, N. 1981. (ed.) Fish Gene Pools. Ecol. Bull., 34. Ecological Bulletins, Stockholm.

RYMAn, N., UtTer, F. AND LAIKre, L. 1995. Protection of intraspecific biodiversity of exploited fishes. Rev. Fish Biol. Fisher., 5, 417-446.

SANCHEZ, J. A., ClABBY, C., RAMOS, D., BLANCO, G., FLAVIN, F., VAZQuez, E. AND POWEll, R. 1996. Protein and microsatellite single locus variability in Salmo salar L. (Atlantic salmon). Heredity, 77, 423-432.

SCHADT, J. 1993. Fische, Neunaugen, Krebse und Muscheln in Oberfranken. Vorkommen und Verbreitung als Grundlage für den Fischartenschutz. Regierungsbezirk Oberfranken, Bayreuth, Germany.

SELANDER, R. K., SMITH, M. H., YOUNG, S. Y., JOHNSON, W. E. AND GENTRY, J. B. 1971. Biochemical polymorphism and systematics in the genus Peromyscus. University of Texas Publ., 7103, 49-90.

SHAKLEE, L. B., ALLENDORF, F. W., MORIZOT, D. C. AND WHITT, G. S. 1990. Gene nomenclature for proteincoding loci in fish. Trans. Am. Fish. Soc., 119, 2-15.

SWOFFORD, D. L. AND SElANDER, R. B. 1989. BIOSYs-1. $A$ computer program for the analysis of allelic variation in population genetics and biochemical systematics. Release 1.7. Illinois Natural History Survey, IL.

THORPE, J. P. 1982. The molecular clock hypothesis. Biochemical evolution, genetic differentiation and systematics. Ann. Rev. Ecol. Syst., 13, 139-168.

THORPE, R. s. 1976. Biometric analysis of geographic variation and racial affinities. Biol. Rev., 51, 407-452.

WARD, R. D., WOODWARK, M. AND SKIBINSKI, D. O. F. 1994. A comparison of genetic diversity levels in marine, freshwater and anadromous fish. J. Fish Biol., 44, 213-232.

WATERSTRAAT, A. 1992. Investigations on the ecology of Cottus gobio L. and other fish species from two lowland streams of Northern Germany. Limnologica, 22, 137-149.

WRIGHT, s. 1978. Variability Within and Among Populations, vol. 2, Evolution and the Genetics of Populations. Chicago University Press, Chicago.

YOUNG, A., BOYLE, T. AND BROWN, T. 1996. The population genetic consequences of habitat fragmentation for plants. Trends Ecol. Evol., 11, 413-418.

ZIMMERMAN, E. G. AND WOOTEN, M. C. 1981. Allozymic variation and natural hybridisation in sculpins, Cottus confusus and Cottus cognatus. Biochem. Syst. Ecol., 4, 341-346. 